\title{
Weighted Product Method for Selection of Superior Seeds Catfish in the Clarias Gariepinus Types (Sangkuriang)
}

\author{
Septya Maharani ${ }^{1, *}$, Swadika Ibnu Persyadha ${ }^{1}$, Dedy Cahyadi ${ }^{1}$, and Mufadhol Mufadhol ${ }^{2}$ \\ ${ }^{1}$ Department of Computer Science, Mulawarman University, East Kalimantan, Samarinda - Indonesia \\ ${ }^{2}$ Department of Computer System, xSTEKOM University, Semarang - Indonesia
}

\begin{abstract}
Sangkuriang catfish is a famous clarias clan fish form his slick and long body non-scaly, with dorsal fins and a long rear fin, which sometimes merges into the tail fin makes it look like a short eel. Catfish also have additional breathing apparatus in the form of modifications from gill arc. There is a pair of fins that are spines bone that is sharp, on the pectoral fin. Some things to consider in order to select superior seedlings of sangkuriang catfish such as size, weight, color, physical defect, even water conditions, which in reality not all catfish farmers know about it. This decision support system using the Weighted Product (WP) method is one of the methods that use the true value in determining the rating of each alternative on each criterion to determine the conclusion of a problem. Based on the results of testing the Selection Decision Support System of the Superior Broodstock Sangkuriang Catfish has an accuracy rate of $87.5 \%$.
\end{abstract}

Keywords: Weighted Product; selection; superior seeds; Clarias Gariepinus; Sangkuriang Catfish.

\section{Introduction}

Catfish is a freshwater fish that is widely cultivated almost throughout the territory of Indonesia. This is because catfish is one of the leading commodities, and has a good market prospect. Some of the advantages of catfish compared with other types of fish that is faster growth and maintenance and feeding easier [1]. Sangkuriang catfish including one type of freshwater fish that has been cultivated commercially by the people of Indonesia. Cultivation of catfish can provide a great income because now catfish is very popular by the community and the price is affordable by all people. This is indicated by the increase in the production of catfish consumption from 2008 amounted to 162.000 tons. Then in 2009 up to 250.000 tons in a year and in 2010 the demand has increased to 273.554 tons in a year. The information indicates that effort is needed to improve the production and quality of catfish seeds [2].

Sangkuriang catfish is the result of a cross from the male dumbo catfish F6 with female catfish dumbo F2. The result of this marriage was found to have superior properties such as the ability to spawn high up to 40-60 thousand eggs once process. Sangkuriang catfish is also more disease resistant, can be maintained in minimal water conditions and better meat quality [3] and can be used as seedlings for catfish, such as Fig 1. There are several things to consider in order to select superior seedlings of sangkuriang catfish, including investment valuation factors in the selection of superior seeds that can provide the necessary consideration in the cultivation of fish farmers such as size, color, physical disability, and a number of whiskers and even conditions water. In fact, not all catfish farmers know that factors, it will be very helpful if there is a system that can provide decision support for catfish farmers. All these factors are combined to get an assessment that can help the decision making process of superior catfish $[1,3]$.

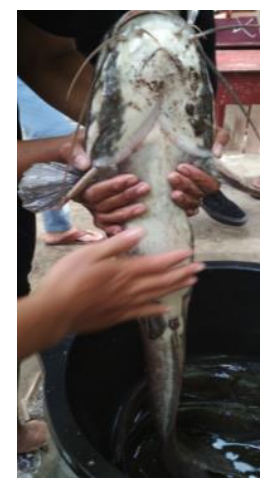

Fig. 1. Sangkuriang Mother Catfish

The decision making process requires the right method that can be used [4], especially for cases such as the selection of superior seeds of this catfish. This research uses a decision making process with Weighted Product (WP)

\footnotetext{
* Corresponding author: septyamaharani@yahoo.com
} 
method [5]. Based on the description that has been described, it will be built a system with the name "Decision Support System Selection of Superior Seeds Sangkuriang Catfish Type (Clarias Gariepinus) Using Weighted Product (WP) Method" to find the best alternative solution.

\section{Research Method}

This research uses research and development models to develop the software engineering [6] and involves several local catfish farming businesses in East Kalimantan, Indonesia.

\subsection{Decision Support System}

Decision Support System (DSS) is a computer-based information system that approaches to generate various decision alternatives to assist certain parties in handling problems using data and models, as in Fig 2. A Decision Support System (DSS) only provides an alternative decision and then submitted to the user to make a decision [7]. Decision making is the result of a selection process from a variety of alternative actions that may be chosen by a particular mechanism to produce the best decision. The decision process is gradual, systematic, consistent, and in every step from the beginning has included all parties, which will give good results [8].

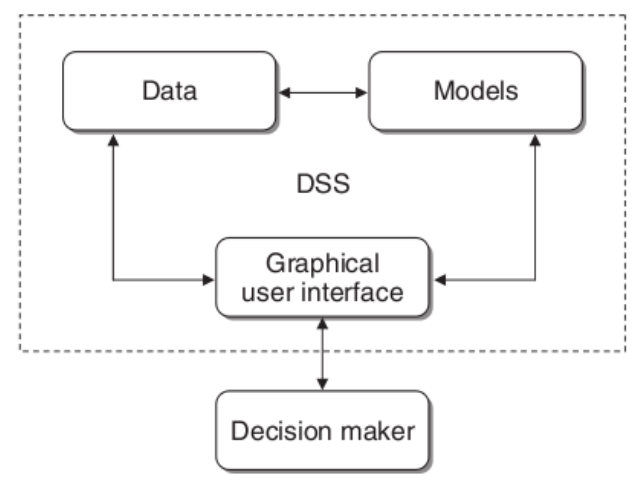

Fig. 2. Component of Decision Support System

The structure of a system includes input, process, output, feedback, environment and system limits. Input is an element that will affect the performance of a system. The process is the whole element to transform the input into an output. The output shows the final product or the consequences of a system. Feedback is the information flow from the output component to the decision maker about the performance of the system. The environment consists of several elements that are outside the system, in the sense of not input, process and output. The system boundary is a separator between a subsystem with another subsystem or system with its environment [9].

\subsection{Weighted Product Method}

The Weighted Product (WP) method is a part of the decision making model by multiplication in connecting an attribute rating. Weight for attributes, serves as a positive rank in the multiplication process between attributes, while the attribute rating serves as a negative rank for the cost attribute $[5,7$ $10]$.

1) Determination of value weight $W$

$$
W j=\frac{w j}{\Sigma w_{j}}
$$

2) Determination of value Vector $S$

$$
\mathrm{S}=\left(W_{i j}^{A W j} \cdot \mathrm{w}\right) .\left(W_{i n}^{A W n} \cdot \mathrm{w}\right) \ldots
$$

3) Determination of value Vector $V$

where:

$$
V \mathrm{jn}=\frac{S i}{\Sigma s i}
$$

$\mathrm{V}=$ Alternative preferences are analogous to vector $\mathrm{V}$

$\mathrm{W}=$ Weight criteria / sub-criteria

$\mathrm{j}=$ Criteria

$\mathrm{i}=$ Alternative

$\mathrm{n}=$ Number of criteria

$\mathrm{S}=$ Alternative preferences are analogous to vector $\mathrm{S}$.

\section{Result and analysis}

\subsection{Criteria for Catfish Variables in Weighted Product}

To determine the criteria for variable catfish as a reference in determining choices, there are 5 (five) fish that will be an alternative choice $(\mathrm{R}): \mathrm{R} 1$ = Sangkuriang catfish is tagged 1, Age 28 month, Weight $3.3 \mathrm{~kg}$, Length $77 \mathrm{~cm}$, Color Dark, It has been processed 2 times. R2 = Sangkuriang catfish is tagged 2, Age 21 month, Weight $1.4 \mathrm{~kg}$, Length $37 \mathrm{~cm}$, Bright Color, Unprocessed. R3 = Sangkuriang catfish is tagged 3, Age 19 month, Weight $2.1 \mathrm{~kg}$, Length $60 \mathrm{~cm}$, Color Dark, It has been processed 1 time. R4 = Sangkuriang catfish is tagged 4 , age 32 months, Weight $1.4 \mathrm{~kg}$, Length $52 \mathrm{~cm}$, Bright Color, It has been processed 3 times. R5 = Sangkuriang catfish is tagged 5, Age 14 month, Weight 2.6 $\mathrm{kg}$, Length $55 \mathrm{~cm}$, Bright Color, It has been processed 5 times and they are 5 (five) variables used as consideration (C) : C1 = Age, C2 = Weight, C3 = Length, C4 = Color, C5 $=$ It has been process/Unprocessed.

\subsection{Decision Making for Level of Preferences}

Decision Support System (DSS) was first introduced by Scott Morton in the early 1970s. He defines DSS as an interactive computer-based system that helps decision makers to use data and models to solve unstructured problems. According to Keen and Morton in 1978, the decision support system (DSS) combines the intellectual resources of individuals with computer capabilities to 
improve the quality of a decision. DSS is a computer-based support system for management decision makers dealing with unstructured issues. In the decision making, the system will give for a level of preference weighting the following preference weight: $\mathrm{W}=(5,4,1.5,3.5,3)$. With preference value such as Table 1, Table 2, Table 3, Table 4, Table 5.

Table 1. Preference Value C1 (Age)

\begin{tabular}{|c|c|c|}
\hline Scale Value & Age of Catfish & Category \\
\hline 2 & $8-11$ months & Minimum Age \\
\hline 3 & $12-17$ months & Enough Age \\
\hline 4 & $18-24$ months & Good Age \\
\hline 5 & $25-36$ months & Maximum Age \\
\hline
\end{tabular}

Table 2. Preference Value C2 (Weight)

\begin{tabular}{|c|c|c|}
\hline Scale Value & Weight of Catfish & Category \\
\hline 1 & $500-750 \mathrm{gr}$ & Minimum Weight \\
\hline 2 & $760-900 \mathrm{gr}$ & Enough Weight \\
\hline 3 & $1-2 \mathrm{~kg}$ & Medium Weight \\
\hline 4 & $2.1-3 \mathrm{~kg}$ & Good Weight \\
\hline 5 & $3-4 \mathrm{~kg}$ & $\begin{array}{c}\text { Very Good Weight } \\
\text { (Maximum) }\end{array}$ \\
\hline
\end{tabular}

Table 3. Preference Value C3 (Length)

\begin{tabular}{|c|c|c|}
\hline Scale Value & Length of Catfish & Category \\
\hline 2 & $10-20 \mathrm{~cm}$ & Minimum Length \\
\hline 3 & $21-40 \mathrm{~cm}$ & Enough Lenght \\
\hline 4 & $41-70$ & Good Length \\
\hline 5 & $71-120 \mathrm{~cm}$ & $\begin{array}{c}\text { Very Good Length } \\
\text { (Maximum) }\end{array}$ \\
\hline
\end{tabular}

Table 4. Preference Value C4 (Color)

\begin{tabular}{|c|c|c|}
\hline Scale Value & Color of Catfish & Category \\
\hline 1 & Dark & Enough \\
\hline 2 & Bright & Very Good \\
\hline
\end{tabular}

Table 5. Preference Value C5 (process/unprocessed)

\begin{tabular}{|c|c|c|}
\hline $\begin{array}{c}\text { Scale } \\
\text { Value }\end{array}$ & Has Been Process & Category \\
\hline 1 & $\begin{array}{c}\text { It has been process 5 } \\
\text { times }\end{array}$ & Process Maximum \\
\hline 2 & $\begin{array}{c}\text { It has been process 1-4 } \\
\text { times }\end{array}$ & $\begin{array}{c}\text { The intensity of } \\
\text { spawning is still in } \\
\text { quota (Enough) }\end{array}$ \\
\hline 3 & Unprocessed & Very Good \\
\hline
\end{tabular}

Each alternative is given a scale value based on the value of preference $\mathrm{C}$, so the values form the Table 6 below.

Table 6. New Value of Preference from Preference C

\begin{tabular}{|c|c|c|c|c|c|}
\hline & $\begin{array}{c}\mathrm{C} 1 \\
\text { (Age) }\end{array}$ & $\begin{array}{c}\mathrm{C} 2 \\
\text { (Weight) }\end{array}$ & $\begin{array}{c}\mathrm{C} 3 \\
\text { (Length) }\end{array}$ & $\begin{array}{c}\mathrm{C} 4 \\
\text { (Color) }\end{array}$ & $\begin{array}{c}\mathrm{C} 5 \\
\text { (It has } \\
\text { been } \\
\text { process) }\end{array}$ \\
\hline R1 & 5 & 5 & 5 & 1 & 2 \\
\hline R2 & 4 & 3 & 3 & 2 & 3 \\
\hline
\end{tabular}

\begin{tabular}{|l|l|l|l|l|l|}
\hline R3 & 4 & 4 & 4 & 1 & 2 \\
\hline R4 & 5 & 3 & 4 & 2 & 2 \\
\hline R5 & 3 & 4 & 4 & 2 & 1 \\
\hline
\end{tabular}

\subsection{The Value of Preference Weighting}

The Weighted Product method uses multiplication as the attribute rating link, where the rating of each attribute must be raised first with the corresponding weight. This process is similar to the normalization process. Previously done weighting first, so the total weight Error! Reference source not found. $=1$ with formula with equations 1 .

So for the improvement of the weights to be:

$$
\begin{aligned}
& \mathrm{W} 1=\frac{5}{5+4+1.5+3.5+3}=0.294 \\
& \mathrm{~W} 2=\frac{4}{5+4+1.5+3.5+3}=0.235 \\
& \mathrm{~W} 3=\frac{1.5}{5+4+1.5+3.5+3}=0.088 \\
& \mathrm{~W} 4=\frac{3.5}{5+4+1.5+3.5+3}=0.205 \\
& \mathrm{~W} 5=\frac{3}{5+4+1.5+3.5+3}=0.176
\end{aligned}
$$

The determine the vector value of $\mathrm{S}$ using the following formula with equations 2

Rank and multiply the value of each of those criteria by the previously fixed weight:

$$
\begin{aligned}
& \mathrm{S} 1=\left(5^{0.294}\right)\left(5^{0.235}\right)\left(5^{0.088}\right)\left(1^{0.205}\right)\left(2^{0.176}\right)=3.053 \\
& \mathrm{~S} 2=\left(4^{0.294}\right)\left(3^{0.235}\right)\left(3^{0.088}\right)\left(2^{0.205}\right)\left(3^{0.176}\right)=3.003 \\
& \mathrm{~S} 3=\left(4^{0.294}\right)\left(4^{0.235}\right)\left(4^{0.088}\right)\left(1^{0.205}\right)\left(2^{0.176}\right)=2.66 \\
& \mathrm{~S} 4=\left(5^{0.294}\right)\left(3^{0.235}\right)\left(4^{0.088}\right)\left(2^{0.205}\right)\left(2^{0.176}\right)=3.062
\end{aligned}
$$$$
\mathrm{S} 5=\left(3^{0.294}\right)\left(4^{0.235}\right)\left(4^{0.088}\right)\left(2^{0.205}\right)\left(1^{0.176}\right)=2.495
$$

Specifies the value of the vector to be used to calculate the preference (Vi) for ranking. The formula is as follows with equations 3 .

So the result of calculating preference (Vi) is as follows:

$$
\begin{aligned}
& \mathrm{V} 1=\frac{3.003}{3.053+3.003+2.66+3.062+2.495}=0.213 \\
& \mathrm{~V} 2=\frac{2.66}{3.053+3.003+2.66+3.062+2.495}=0.21 \\
& \mathrm{~V} 3=\frac{3.062}{3.053+3.003+2.66+3.062+2.495}=0.186 \\
& \mathrm{~V} 4=\frac{2.495}{3.053+3.003+2.66+3.062+2.495}=0.214 \\
& \mathrm{~V} 5=\frac{3.053+3.003+2.66+3.062+2.495}{3.0174}
\end{aligned}
$$


From the above calculation, V4 value shows the greatest value so that in other words $\mathrm{V} 4$ is the best alternative choice.

\section{Conclusion}

The result of this system is obtained from the Weighted Product (WP) method, where based on the existing alternative is formed into a matrix and then calculated using the equations that exist in the WP method so that can be obtained the alternative recommendation of sangkuriang catfish to choose superior breeds as a tool for the catfish breeders.

\section{Recommendations}

The next, this system of Decision Support System Selection of Superior Seeds Sangkuriang Catfish Type (Clarias Gariepinus) Using Weighted Product (WP) Method can be developed online with managing network traffic [11] and the system can be accessed by mobile phone [12]. This system can be combined with expert systems using rulebased reasoning method [13] and the system can be saved in the cloud computing [14].

\section{Acknowledgment}

This research of collaboration between the Department of Computer Science, Faculty of Computer Science and Information Technology, Mulawarman University, East Kalimantan, Indonesia and Departement of Computer System, STEKOM Semarang, Majapahit Street 605, phone +62246723456, +62246710144, Semarang, Indonesia.

\section{References}

1. S.O. Sitompul, E. Harpani, B. Putri, Effect of Density of Azolla sp. Different Against Water Quality and Growth of Sangkuriang Catfish Seed (Clarias Gariepinus) On a System Without Substitute Water, Journal of Engineering and Techniques of Aquaculture 1 (1), pp.17-24 (2012)

2. J. Jaja, S. Ani, S. Komar, Business Enlargement and Marketing of Catfish and Development Strategy at UD Sumber Rezeki Parung, West Java, Journal of Development Management on Small Scale Industry 8 (1), 45-56 (2013)

3. H.B. Lumentut, S. Hartati, Decision Support System for Selecting Freshwater Aquaculture Using AF-TOPSIS, Indonesian Journal of Computing and Cybernetics Systems 9 (2), 197-206 (2015)

4. M.S. Pfaff, G.L. Klein, J.L. Drury, Supporting Complex Decision Making Through Option Awareness, Journal of Cognitive Engineering and Decision Making 7 (2), 155-178 (2013)

5. R.N.P. Atmojo, A.D. Cahyani, Y. Lie, Simulation Modeling of Tablet PCs Selection Using WeightedProduct Algorithm, International Journal of Applied Mathematical Sciences 8 (115), 5705-5719 (2014)

6. M. Mufadhol, S. Siswanto, D.D. Susatyono, U.D. Maya, The Phenomenon of Research and Development Method in Research of Software Engineering, International Journal of Artificial Intelligence Research 1 (1), 1-5 (2017)

7. Z. Xu, Ranking Alternatives Based on Intuitionistic Preference Relation, International Journal of Information Technology and Decision Making 13 (6), 1259-1281 (2014)

8. D.F. Li,.Multi-Attribute Decision-Making Models and Methods Using Intuitionistic Fuzzy Sets, Journal of Computer and System Sciences 7 (3), 73-85 (2005)

9. K. Xu, J. Zhou, R. Gu, H. Qin, The Compound Consistency Induced Ordered Weighted Averaging Operator and Its Application to Reservoir Operation, IEEE Xplore in the 7th International Conference on Fuzzy Systems and Knowledge Discovery (2010)

10. A. Karami, R. Johannson, Utilization of Multi Attribute Decision Making Techniques to Integrate Automatic and Manual Ranking of Options, Journal Of Information Science And Engineering 30 (4), 519-534 (2014)

11. M. Mufadhol, G. Aryotejo, A. Wibowo, Netscan and Networx for Management Bandwidth and Traffic with Simple Routing, TELKOMNIKA Telecommunication Computing Electronics and Control 15 (1), 464-470 (2017)

12. A. Wibowo, G. Aryotejo, M. Mufadhol, Accelerated Mobile Pages from JavaScript as Accelerator Tool for Web Service on E-Commerce in The E-Business, International Journal of Electrical and Computer Engineering, 8 (4),2399-2405 (2018)

13. M. Mufadhol, G. Aryotejo, D.Y. Kristiyanto, Rule Based Reasoning Method for Safety Room by Means of Temperature Sensor and Motion Detector, International Journal of Advanced Science Letters 23 (3), 2481-2483 (2017)

14. G. Aryotejo, D.Y. Kristiyanto, M. Mufadhol, Hybrid cloud: bridging of private and public cloud computing, Journal of Physics: Conference Series 1025 (012091), 1-7 (2018) 